\title{
The effect of leadership behaviours on followers' experiences and expectations in a safety-critical industry
}

\begin{tabular}{|c|c|}
\hline \multicolumn{2}{|c|}{$\begin{array}{l}\text { Authors: } \\
\text { Christiaan G. Joubert }^{1} \\
\text { Joseph A. Feldman }\end{array}$} \\
\hline \multicolumn{2}{|c|}{$\begin{array}{l}\text { Affiliations: } \\
{ }^{1} \text { Air Traffic and Navigation } \\
\text { Services, South Africa }\end{array}$} \\
\hline \multicolumn{2}{|c|}{$\begin{array}{l}{ }^{2} \text { Graduate School of Business } \\
\text { Leadership, University of } \\
\text { South Africa, South Africa }\end{array}$} \\
\hline \multicolumn{2}{|c|}{$\begin{array}{l}\text { Corresponding author: } \\
\text { Joseph Feldman, } \\
\text { feldmja@unisa.ac.za }\end{array}$} \\
\hline \multicolumn{2}{|c|}{$\begin{array}{l}\text { Dates: } \\
\text { Received: } 01 \text { Dec. } 2015 \\
\text { Accepted: } 15 \text { Mar. } 2017 \\
\text { Published: } 26 \text { Apr. } 2017\end{array}$} \\
\hline \multicolumn{2}{|c|}{$\begin{array}{l}\text { How to cite this article: } \\
\text { Joubert, C.G. \& Feldman, J.A., } \\
\text { 2017, 'The effect of } \\
\text { leadership behaviours on } \\
\text { followers' experiences and } \\
\text { expectations in a safety- } \\
\text { critical industry', South } \\
\text { African Journal of Economic } \\
\text { and Management Sciences } \\
\text { 20(1), a1510. https://doi. } \\
\text { org/10.4102/sajems. } \\
\text { v20i1.1510 }\end{array}$} \\
\hline \multicolumn{2}{|c|}{$\begin{array}{l}\text { Copyright: } \\
\text { (c) 2017. The Authors. } \\
\text { Licensee: AOSIS. This work } \\
\text { is licensed under the } \\
\text { Creative Commons } \\
\text { Attribution License. }\end{array}$} \\
\hline \multicolumn{2}{|l|}{ Read online: } \\
\hline 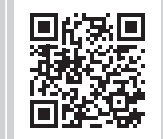 & $\begin{array}{l}\text { Scan this QR } \\
\text { code with your } \\
\text { smart phone or } \\
\text { mobile device } \\
\text { to read online. }\end{array}$ \\
\hline
\end{tabular}

Background: Motivation for this study was found in concern expressed by civil aviation organisations that specialists in the air navigation services provider sector require appropriate and beneficial organisational leadership to encourage, enable and manage transformation within this highly structured setting. Also, academic research puts emphasis on a need for investigations of the roles, expectations and requirements of followers in the leadershipfollowership relationship. Followers' experiences and expectations of leadership behaviours in an air navigation service provider (ANSP) organisation were investigated and served as orientation and setting applicable to this study.

Aim: The aim of the research was to identify and understand how follower experiences and expectations of leadership behaviours in a safety-critical commercial environment can affect leadership training and growth. The above-mentioned motivated this investigation of leadership traits and behaviours within an explicit context and from a follower's viewpoint.

Setting: The setting for the study was twenty two Air Traffic and Navigation Services Company sites where followers' experiences and expectations of leadership behaviours in an air navigation service provider (ANSP) organisation were investigated and served as orientation and setting applicable to this study.

Methods: An ethnographic case study research style was adopted and followed because it allowed for an all-inclusive, holistic narrative report and interpretation. The samples for the quantitative and qualitative components of this study were parallel and methods employed addressed different aspects of the phenomenon, which allowed for a mixed methods research design. A one-way causality in the research design was observed because traits of followers that might influence leaders' behaviours were excluded. Data were collected by means of a Leader Trait and Behaviour Questionnaire completed by participants, individual interviews and focus group consultations.

Results: Research findings dispensed a deeper appreciation of followers' epistemological and ontological views, within a specified context, which were supported by a common need to achieve organisational safety objectives. A practical managerial benefit was found in the insights presented by followers of leadership, which can possibly benefit leadership development and training needs, along with training and advancement of followers.

Conclusions: Research findings potentially add to enhancing understanding of leadership development theory, synonymous with a safety-critical commercial setting. A critical insight into the 'unexplored' leadership behaviour qualities found within a safety-critical milieu is subsequently offered.

\section{Introduction}

\section{Orientation}

Outcomes of a global survey conducted by the Civil Air Navigation Services Organisation (CANSO 2010) of air navigation service providers (ANSPs) acknowledged the existence of explicit safety and culture barriers. For example, information not shared with management, because of lack of trust, exhibited a limitation. Instances of punitive actions serve as evidence of a cultural barrier. The above mentioned facts are attributed to leaders who exhibit egotistical, autocratic or domineering management styles. In contrast, it may be contended that within

Note: This article is partially based on the author's Doctor of Business Leadership thesis at the University of South Africa, South Africa, with promoter: Dr J.A. Feldman, received July 2014, available here: http://uir.unisa.ac.za/bitstream/handle/10500/18687/thesis joubert_cg.pdf?isAllowed=y\&sequence=1 
a highly regulated situation, it is anticipated that leadership behaviours should likely encourage follower actions, especially when compliance with strict rules is expected. Consequently, leadership behaviours may well support and encourage such rule-based conduct. Incongruity in this case possibly exists, whereby current leadership behaviours may not necessarily contribute to compliance expectations and activities. It is thus postulated that a thorough appreciation of prevailing leader qualities and performances can probably be found in encounters, observations and thoughts disclosed by followers. These reports may recognise and critically describe leadership behaviours that influence followership. Accordingly, an expressive follower-emphasised study was warranted so as to find and uncover noticeable leadership behaviours. This study was conducted within a safetyconscious, highly regulated and technology-driven industry (aviation industry), a safety-critical sector (air navigation services) and a specific safety setting, namely, an air traffic and navigation services provider.

\section{Literature review}

When considering studies conducted by Avolio, Walumbwa and Weber (2009), Whitener (2001), Kellerman (2007) and Yukl (2005), it can be argued that leader qualities and behaviours can be examined from, amongst others, an organisational, leadership or a follower perspective. Leadership theories and paradigms tend to focus on leaders' reports on leadership (Kellerman 2007; Shamir \& Howell 1999; Vroom \& Jago 1988). Studies have accentuated leaders as if they were completely separate from those they lead, while followers have tended to be acknowledged as an undifferentiated constituent (Boezeman \& Ellemers 2008; Collinson 2006; Riggio, Chaleff \& Lipman Biumen 2008). This reported misconception may advance an argument for the important role that followers play in the leader-follower relationship and organisational performance (Boccialetti 1995; Chaleff 1995; Kellerman 2008; Kelley 1992).

Leadership encompasses social interactions between leaders and followers. Emotional awareness and regulation influence the quality of these interactions and relationships (Hill \& Lineback 2011; Hur 2008; Ibarra \& Barbulescu 2010; Madera \& Smith 2009; Wong \& Law 2002). Howell and Haii-Merenda (1999) explain that in leadership research, an affiliation of some sort between leader and follower is anticipated. Also, it is further proposed that the type and value of this relationship are critical when associating leader behaviour and follower response. Cropanzano and Mitchell (2005) found that within current management research, the social exchange theory has been afforded the most attention, especially in terms of workplace relationships. Social exchange theory acknowledges that specific workplace antecedents lead to interpersonal connections - denoted as social exchange relationships (Cropanzano et al. 2001). Consequently, individuals regulate their interactions with other individuals based on a self-interest consideration of the efforts and benefits of such engagements (Brown \& Mitchell 2010). People thus develop attitudes towards other people and things in the context of estimated personal benefits and costs to result from such encounters (Brown \& Trevino 2006). In addition, Whitener (2001) has found that research imbedded in social exchange theory has revealed that employees' obligation to the organisation stems from their perceptions of the employers' commitment to and support of them (Eisenberger, Fasolo \& Davis-LaMastro 1990; Hutchison \& Garstka 1996; Settoon, Bennett \& Liden 1996; Wayne, Shore \& Liden 1997).

A study that postulates leadership and followership as interrelated events requires a methodological focus on interactions, connections, dependences and exchanges when investigating specific encounters, matters or situations (Castro, Perinan \& Bueno 2008; Ilies, Morgeson \& Nahrgang 2005; Kupers 2007; McCann, Langford \& Rawlings 2006; Mushonga \& Torrance 2008; Wood 2005). These inferred associations can also be explained as psychological contracts that refer to an individual's system of beliefs grounded in commitments articulated or implied (Rousseau 2010). Leaders play a prominent role in the creation of the views followers have of leadership (Gray \& Densten 2007). These views can be underlined with reference to the history of leadership theories as mapped by Baicher (2005) being:

- 1920s: Emergence of trait model (Great man theories).

- 1940s: Behavioural model.

- 1950s and 60s: Situational/Contingency model.

- 1970s: Advent of neo-charismatic leadership model (transactional and transformational).

- 1990s-2000s: Expansion of ethical/spiritual theories (ethical, shared, spiritual theories) and return of traits, universal and cultural-specific leadership.

Knowledge of the leadership-followership subject advocates that research in leadership studies leans towards centring the leader as the main point and principal element of the leaderfollower relationship, mindful that such focus is really from the leader's perspective (Den Hartog \& Belschak 2012; Hollander 1992a, 1992b; Kellerman 2004; Kirchhubel 2010; Lord \& Brown 2004; Mayo \& Pastor 2007; Shamir 2007; Wang et al. 2014; Yukl 2005). Because followers are exposed to a leader's style and actions, they are positioned to evaluate its effects on the leader-follower relationship (Castro et al. 2008; Hollander 1995; Kirchhubel 2010; Van Vugt 2006).The previously mentioned thus draws attention to a follower perspective. Identifying and exploring explicit follower views that are synonymous with both inspirational and unfavourable leadership behaviours depend on responses and testimonies from followers regarding these behaviours. Hence, follower accounts, remarks, descriptions, incidents, clarifications, structured responses and perceptions served as data essential for this study.

Leadership traits and behaviours highlight social interactions and emotional filters contained by leader-follower relationships. Moreover, leaders and followers (individually and collectively) delineate leadership and followership from diverse perspectives. However, leadership is understood as a 
complex set of behaviours found within a specific setting that directs conduct. A leader's actions can inspire commitment or alienate followers (Banutu-Gomez 2004). Organisational progress and performance may be restrained by paltry leadership (Morris, Ely \& Frei 2011). This study attempted to investigate reported experiences and expectations of followers with regard to leadership behaviour qualities within an ANSP. Both inspirational and discouraging leadership experiences and styles were probed. Because of this exclusive and limited focus on followers, a one-way causality in the research design was followed.

Followership has been hailed as an understudied subject in the academic literature and viewed as an underappreciated topic amongst practitioners (Bjugstad et al. 2006). Avolio et al. (2009) found that one of the most interesting omissions in theory and research on leadership is the lack of discussions pertaining to followership and its impact on leadership. Although it has always been important, the study of followership has now become even more important and noteworthy with the advent of the information age as well as vast changes in the workplace (Bjugstad et al. 2006; Shamir 2007; Stetz, Stetz \& Bliese 2006). Bjugstad et al. (2006) describe followership as the capability to effectively follow instructions, while also supporting the efforts of a leader in pursuit of organisational success. Followership schemas develop through socialisation and previous experiences with both leaders and other followers (Hogg 2001). These are kept in memory and actuated when followers interact with leaders or other followers (Hogg 2001). In terms of followership, the responses selected and employed by followers based on experiences and expectations of leadership behaviours and followership deserved investigation. It was accepted that follower responses can provide content-specific and contextspecific information that can be used for organisational purposes, such as leadership development initiatives. Furthermore, acquiring insight into influences that shape followers' sentiments and beliefs can aid understanding of followers' cognitive frameworks and contemplative practices. The mentioned cognitive frameworks are based on the assumption that individuals reason by trying to envisage the possibilities compatible with what they know or believe (Johnson-Laird 2013).

\section{Research emphasis}

As a point of departure, it was accepted that one's past experiences are likely to influence one's current and future views. In lieu of this statement, it was recognised that follower experiences can be presented as personal, noteworthy or meaningful encounters, steered by reflective thoughts. As a result, leadership behaviours and qualities endured can influence followers' mental models and subsequently encourage critical appraisals of leadership. Mental model data can consist of ephemeral discernments or thoughts, as well as long-term knowledge and beliefs, and such data are accessible by means of introspection (JohnsonLaird 2013; Knauff et al. 2013). As a result, follower expectations can be based on predictions and existing beliefs.
Consequently, the researchers depended on follower insights to comprehend and appreciate followers' epistemological and ontological views of leadership (limited to a specific context). It was contemplated that these insights could be valuable to appraise leadership training and development theory.

The research problem emerged as a result of the research gap in the academic literature on follower behaviour.

It is articulated as follows: follower experiences and expectations of leadership behaviours have not been effusively amassed, scrutinised, understood, structured and utilised to further aid leadership development. It is imperative that it can now be done within a safety-critical commercial environment to support the realisation of this environment's goals and objectives.

The research problem was addressed through the answering of the following research questions:

- Question1: How do followers within an ANSP describe leadership behaviour qualities in terms of the impact of these behaviour qualities?

- Question 2: How do current leadership behaviour qualities enthuse followership within an ANSP?

- Question 3: How do current leadership behaviour qualities demotivate followership within an ANSP?

- Question 4: How can follower experiences and expectations of leadership behaviours within an ANSP benefit leadership training and development needs analyses?

The remainder of this article highlights the research design, analysis, findings and discussion. The research design is presented inclusive of the research approach, paradigm and strategy and method. The research findings furnish the quantitative and qualitative insights as well as the triangulated results. Links with the research questions are offered in the discussion of the findings, including recommendations and suggestions for future research.

\section{Research design Research approach}

Mixed methods research is useful when a need arises to answer questions that cannot be addressed by qualitative or quantitative approaches alone (Creswell 2003; Greene, Caracelli \& Graham 1989). Johnson and Onwuegbuzie (2004) add that a mixed method inquiry considers induction (or discovery of patterns), deduction (testing theories and hypotheses) and abduction (uncovering and presenting the best of a set of explanations for understanding one's results). Mixed methods research integrates aspects from both qualitative and quantitative paradigms to deliver converging findings in the context of intricate research questions. Yin (2011) adds that mixed methods research offers an option that incorporates the similarities and dissimilarities in qualitative and quantitative methods. Accordingly, the 
researchers introduced and followed a mixed methods research approach that facilitated and integrated both qualitative and quantitative investigations.

\section{Research paradigm and strategy}

Following deliberation, an ethnographic research case study strategy was preferred. Because an ethnographic interview requires respectful listening (Heyl 2001), the desired deeper descriptions were more viable. This necessitated listening for shifts in verbal variation, inconsistencies, topics avoided and hesitations. Furthermore, the contextual orientation needed to be understood from an organisational viewpoint. This decision thus required a context-specific research focus and boundary, which lead to the use of a supportive case study. It was accepted that a case is an empirical inquiry that studies a current phenomenon within its real-life context and is typically used when the boundaries between phenomenon and context are not apparent (Kohlbacher 2005; Walshe et al. 2004; Yin 2003). Yin (2003) adds that the typical need for case studies arises out of the aspiration to understand complex social phenomena. In this research, the apparent goal of the case study was to reveal patterns, find meanings, construct inferences and build theory (Kohlbacher 2005; Noor 2008; Patton \& Appelbaum 2003). The case study method allowed the researchers to follow an all-inclusive and meaningful trail of actual events as experienced and presented by followers.

\section{Research method}

\section{Research setting}

Leadership suggested in this context comprised ANSP operations' organisational management levels. So, a leader, for the purpose of this study, is an officially appointed person that is responsible for the performance of a group of employees/followers who report directly to him or her. $\mathrm{He}$ or she is also formally responsible for the realisation of organisational goals through the group's performance. Follower boundaries pertinent to this study excluded ANSP management as well as non-operations personnel.

\section{Population}

The target population amounted to 459 ANSP employees and comprised 293 air traffic control officers (ATCO), 123 air traffic service officers (ATSO) and 43 aeronautical information management officers (AIMO) in employment of an ANSP. A total of 22 operational centres served as accessible research sites.

\section{Sampling}

Saunders, Lewis and Thornhill (2007) found that nonprobability sampling is more commonly used when following a case study strategy. Qualitative data collection had to be collected from a subgroup of the accessible population (comprising non-management operations employees employed by the ANSP). A non-probability convenient sample was thus drawn. Fifteen followers were individually interviewed, and nine followers participated in the focus group interviews. In turn, quantitative data had to be gathered from a subgroup of the accessible population (145 non-management employees employed by the ANSP participated). This subgroup comprised 85 ATCO, 46 ATSO and 14 AIMO from 21 ANSP operational centres. The researchers' sampling decision was based on the accessibility of participants and willingness of the participants to participate. This decision informed the type of sample drawn, being a non-probability convenient sample.

\section{Data collection methods}

A Leader Trait and Behaviour Questionnaire, individual interviews and focus group interviews served as data collection methods. The Leader Trait and Behaviour Questionnaire was found to be suitable for this study because the term 'leader traits' denotes personality factors that are observable both within and outside the context of work (Wilson 2004) and 'leader behaviours' focus on the activities engaged in by the leader, including his or her characteristic approach, which suggests his or her effectiveness (Wilson 2004). This decision is aligned to the literature review where it was suggested that leadership behaviours may be conceptually framed as subdivisions that will allow followers to describe their realities. Subdivisions of the questionnaire include the leader's behaviours (as an individual), the leader's interaction with the team (described as team behaviours) and the leader's behaviour within a specific organisational setting. The Leader Trait and Behaviour Questionnaire consisted of Wilson's (2004) effective developmental leader trait instrument (EDLTI) and the effective developmental leader behaviour instrument (EDLBI). Wilson (2004) identified six leader traits ('Dedicated', 'Practical', 'Cooperative', 'Assertive', 'Personable' and 'Analytical') and seven leader behaviours ('Focused', 'Supportive', 'Developer', 'Delegator', 'Advisor', 'Competitive' and 'Charismatic') considered to be synonymous with leader qualities that encourage followership. In summary, it should be noted that the aptness of this questionnaire was because of its focus (leader performance), its specific areas of interest (leader trait and behaviours), its leader development emphasis as well as favourable and supportive pilot testing results.

Qualitative data collection relied on the use of individual and focus group interview questions. These were formulated in terms of themes identified as key constructs derived from the literature review. Therefore, it was necessary to understand how followers delineate leadership traits and behaviours in terms of significance of these behaviour qualities. It was envisaged that these views had to be understood and valued in terms of the juxtaposition of followers' cognitions directed by their mental models and leadership behaviours reported within the ANSP. Further understanding also relied on juxtaposition that provided deeper understanding regarding the second and third key constructs. The second key construct was aimed at understanding leadership traits and behaviours 
that motivated followership. The third key construct highlighted leadership traits and behaviours that discouraged followership. The second and third key constructs demanded understanding of individual leadership behaviours, team leadership behaviours, organisational leadership behaviours and network behaviours. Qualitative data collection continued until saturation (Lincoln \& Guba 1985; Ohman 2005) was reached. Interviews were reinforced by field notes completed during each interview. This use of field notes corresponds to Mouton's (2001) and Yin's (2003) views that interviews can be enhanced when additional sources of evidence are used. Mentioned is specifically pertinent in case study research within a specific context (Mouton 2001; Yin 2003).

\section{Analyses}

Interview data analysis was performed at a basic level of analysis and an interpretative level of analysis. Inductive codes, identification of themes, patterns and relationships that were emerging across data were developed. The truthfulness of the qualitative data analysis was confirmed by an external codifier.

Emerging categories from individual interviews (Table 1 is presented as an example) and focus group interviews identified followers' experiences of leadership as synonymous with assertive leadership actions, and they reported that leadership foci were supportive of organisational goals. In support, statements serve as evidence such as, for example:

'fill the tasks that are assigned to you, obeying by the rules or the rules of the leader, act to the instructions' [Participant 240, Female, Aeronautical Information Management Officer]

Furthermore, an expectation to move towards a transformational leadership style that is inclusive of expressed follower development aspirations was highlighted. In support, it was, for example, stated: 'like to follow, directs people, qualities being selfless, confidence, outspoken, intelligent and wise, monitor his people's needs'. [Participant 236, Male, Air Traffic Controller]

Similarly, transformational and pragmatic leadership experiences and expectations (from a follower perspective) were presented as emerging categories resulting from individual interviews. In this regard, statement examples are:

'honest and outspoken, approachable but they can approach you too, are structured, well structured, willing to listen'. [Focus Group 224, Females, Air Traffic Controllers]

However, specific mention was made by followers of encountered leadership concerns such as leader-follower communication problems and lack of leader support in terms of workplace task and relationship matters. Comparable emerging categories were found as a result of focus group data analysed. Noteworthy, in this case, was an additional emerging category that assisted to explain followership within the ANSP. Mentioned was a passive follower state, described in terms of behaviours suggesting inter alia compliance, obedience, uncertainty and deference.

Leadership trait and behaviour variances were derived from responses to the Leader Trait and Behaviour Questionnaire. Descriptive statistics were used to explain continuous variables. The researchers adopted limits (termed 'noteworthy' and 'negligible') with reference to the 5 -scale Likert-style rating scale interpretation (a mean of 3.50 was considered). Subsequently, data were standardised and interpreted with reference to developed and desired leader traits and behaviours ('noteworthy') and emerging/ undeveloped but desired leader traits and behaviours ('negligible'). Common leader trait items were identified by the three vocational groups. These leader trait items were also part of the common trait items that were acknowledged by the three vocational groups collectively (as per Tables 2-5).

TABLE 1: Categories and associated subcategories (individual interviews).

\begin{tabular}{|c|c|c|}
\hline Categories & Subcategories and codes & Examples of narrative codes \\
\hline Transformational leaders & $\begin{array}{l}\text { Subcategories: Driven leader, charismatic leader, supportive leader and } \\
\text { assertive leader. Examples of codes (key descriptive terms): Impact- } \\
\text { directed, moral-fibre, self-actualisation, to be successful, successful } \\
\text { person, convincing. }\end{array}$ & $\begin{array}{l}\text { 'leadership is less about your title and more about impact' [Participant } \\
225, \text { Male, Air Traffic Services Officer]; } \\
\text { 'to realise our potential' [Participant 240, Female, Aeronautical } \\
\text { Information Management Officer]; } \\
\text { 'success which is true leadership' [Participant 225, Male, Air Traffic } \\
\text { Services Officer]; } \\
\text { 'somebody you can look up to, you can follow, they inspire, they } \\
\text { motivate, they lead' [Focus Group 224, Females, Air Traffic Controllers]. }\end{array}$ \\
\hline Pragmatic leaders & $\begin{array}{l}\text { Subcategory: Practical communicator (leader). Examples of codes (key } \\
\text { descriptive terms): Effective communication, create rapport, stimulate } \\
\text { peer discussions, informer. }\end{array}$ & $\begin{array}{l}\text { 'approachable, also able to delegate tasks which I think is highly } \\
\text { important' [Participant 232, Male, Aeronautical Information Management } \\
\text { Officer]; } \\
\text { 'able to communicate better with the leadership' [Participant 237, Male, } \\
\text { Aeronautical Information Management Officer]; } \\
\text { 'I feel welcome and I haven't experienced any negative stuff' [Participant } \\
239, \text { Male, Aeronautical Information Management Officer]; } \\
\text { 'leaders are always around so the relationship is good' [Participant 240, } \\
\text { Female, Aeronautical Information Management Officer]; } \\
\text { 'they are easy to access' [Participant 241, Female, Aeronautical } \\
\text { Information Management Officer]. }\end{array}$ \\
\hline Leader limitations & $\begin{array}{l}\text { Subcategories: Unsupportive leader and poor communication (leader). } \\
\text { Examples of codes (key descriptive terms): Unwilling to listen, ineffective } \\
\text { communication, confusing replies. }\end{array}$ & $\begin{array}{l}\text { 'not being able to speak to or not being able to lead, don't know how to } \\
\text { lead' [Participant 241, Female, Aeronautical Information Management } \\
\text { Officer]; } \\
\text { 'not being able to delegate' [Participant 228, Female, Air Traffic } \\
\text { Controller]; } \\
\text { 'rule by terror' [Participant 229, Female, Air Traffic Controller]; } \\
\text { 'closed door of personality' [Participant 229, Female, Air Traffic } \\
\text { Controller]; } \\
\text { 'having a overbearing nature' [Participant 230, Male, Air Traffic } \\
\text { Controller]. }\end{array}$ \\
\hline
\end{tabular}


TABLE 2: Noteworthy leader trait factors and items (noted as ' $\mathrm{B}$ ').

\begin{tabular}{lllll}
\hline ATCO, AIMO and ATSO combined & Factor & $N$ & Mean & Standard deviation \\
\hline Dedicated & B33, B19, B32, B21, B11, B34, B48, B63, B54, B1, B42 and B55 & 145 & 3.61 \\
Practical & B27, B2, B62, B57 and B47 & 145 & 3.56 \\
Cooperative & B9 & 145 & 3.52 & 0.879 \\
Assertive & B5, B6, B43, B23, B17, B12, B59, B51, B31 and B7 & 145 & 3.67 \\
Personable & B44, B49 and B26 & 145 & 3.57 \\
Analytical & B14 and B4 & 145 & 0.909 \\
\hline
\end{tabular}

AIMO, aeronautical information management officers; ATCO, air traffic control officers; ATSO, air traffic service officers.

TABLE 3: Leader trait factors and items (noted as ' $\mathrm{B}$ ').

\begin{tabular}{lllll}
\hline ATCO, AIMO and ATSO combined & Factor & $N$ & Standard deviation \\
\hline Dedicated & B20, B24, B25, B61, B15 and B20 & 145 & 3.41 \\
Practical & B56, B52, B22, B53, B60, B39 and B40 & 145 & 3.35 \\
Cooperative & B30, B35, B16, B3, B38, B18, B45, B37 and B46 & 145 & 0.972 \\
Assertive & B41 and B50 & 145 & 3.37 \\
Personable & B28, B58, B36, B29 and B10 & 145 & 3.41 \\
Analytical & B8 and B13 & 145 & 3.32 \\
\hline
\end{tabular}

AIMO, aeronautical information management officers; ATCO, air traffic control officers; ATSO, air traffic service officers.

TABLE 4: Leader behaviour factors and items (noted as ' $C$ ').

\begin{tabular}{llll}
\hline ATCO, AIMO and ATSO combined & Factor & $N$ & Standard deviation \\
\hline Focused & C45, C87, C39, C85, C77, C60, C90 and C40 & 145 & 3.63 \\
Supportive & C2, C46, C47, C11, C84 and C8 & 145 & 3.58 \\
Developer & C88 & 145 & 3.899 \\
Advisor & C43 & 145 & 3.965 \\
Competitive & C83, C61 and C81 & 145 & 3.55 \\
Delegator & C9, C10, C15, C26, C31, C3, C27 and C25 & 145 & 3.64 \\
Charismatic & C13, C14 and C21 & 145 & 3.69 \\
\hline
\end{tabular}

AIMO, aeronautical information management officers; ATCO, air traffic control officers; ATSO, air traffic service officers.

TABLE 5: Leader behaviour factors and items (noted as ' $C$ ').

\begin{tabular}{|c|c|c|c|c|}
\hline ATCO, AIMO and ATSO combined & Factor & $N$ & Mean & Standard deviation \\
\hline Focused & $\mathrm{C} 86, \mathrm{C} 65, \mathrm{C} 74, \mathrm{C} 76, \mathrm{C} 91, \mathrm{C} 89, \mathrm{C} 79$ and $\mathrm{C} 75$ & 145 & 3.41 & 0.917 \\
\hline Supportive & $\mathrm{C} 71, \mathrm{C} 23, \mathrm{C} 50, \mathrm{C} 22, \mathrm{C} 12, \mathrm{C} 94, \mathrm{C} 17, \mathrm{C} 48, \mathrm{C} 92, \mathrm{C24}, \mathrm{C56}, \mathrm{C} 44, \mathrm{C} 20, \mathrm{C} 59, \mathrm{C} 80, \mathrm{C} 55$ and C5 & 145 & 3.29 & 1.004 \\
\hline Developer & $\mathrm{C} 1, \mathrm{C} 6, \mathrm{C} 41, \mathrm{C} 62, \mathrm{C} 29, \mathrm{C} 34, \mathrm{C} 33, \mathrm{C} 51, \mathrm{C57}, \mathrm{C} 16$ and C49 & 145 & 3.19 & 0.998 \\
\hline Advisor & $\mathrm{C} 63, \mathrm{C} 38, \mathrm{C} 82, \mathrm{C} 42, \mathrm{C} 64, \mathrm{C} 66, \mathrm{C} 36, \mathrm{C} 67, \mathrm{C} 37, \mathrm{C} 68$ and $\mathrm{C} 70$ & 145 & 3.33 & 1.014 \\
\hline Competitive & $\mathrm{C} 69, \mathrm{C} 54, \mathrm{C} 58, \mathrm{C} 53, \mathrm{C} 72$ and $\mathrm{C52}$ & 145 & 3.17 & 0.950 \\
\hline Charismatic & $\mathrm{C} 19, \mathrm{C} 18$ and $\mathrm{C} 73$ & 145 & 3.21 & 0.995 \\
\hline
\end{tabular}

AIMO, aeronautical information management officers; ATCO, air traffic control officers; ATSO, air traffic service officers.

In summary, quantitative results stressed the presence of specific operational leader traits and behaviours within the ANSP. A one-way analysis of variance (ANOVA) was performed because it calculated significant difference between the population's means. In addition, a KruskalWallis test was employed as a nonparametric alternative to the one-way between-groups ANOVA. Scores were converted to ranks, and the mean ranks for each group were compared. No conclusive evidence of significant difference between the groups could be claimed because of the variability of data. No significant differences $(p<0.05)$, between the three vocational groups (ATCO, ATSO and AIMO), were thus prominent. The quantitative results not only emphasised the positive leader actions and experiences but also showed areas where enhancements were required.

\section{Validity and reliability of the results of the analyses}

\section{Validity}

Triangulation results signified consistency. Data and method triangulation were effected. In support of data triangulation, evidence from multiple empirical sources was used to crosscheck information. Each portion of the evidence was assessed by associating it with other kinds of evidence on the same issue. In support of method triangulation, the evidence was assessed by collecting other evidence on those sources, using different research methods (e.g. by using questionnaires and interviews). The first phase of data and method triangulation relied upon external codifier feedback, member-checking comments, individual interview data and data from individual interview field notes. In this case, consistencies 
were found in an individual interview and individual interview field note-derived categories. The second phase of triangulation considered external codifier feedback, memberchecking comments, focus group interview data and data from focus group interview field notes. Again, consistencies were apparent. The third phase of triangulation depended on external codifier feedback, member-checking comments, all focus group interview data and all individual interview data. In this case, leader and leadership descriptive experiences as well as follower needs and concerns received different portrayals; however, consistencies were noted in terms of desired and undesired qualities.

The final phase of triangulation considered the Leader Trait and Behaviour Questionnaire data, all focus group interview data and all individual interview data. Of interest was that although the theme remained similar, differences were noted in terms of detailed focal points. Differences were found in terms of leader traits, leader behaviours, leadership styles as well as follower characteristics. However, these also provided impetus for convergence. These differences were considered as diverse perspectives that were related to an integrated study of contextbound leadership. The researchers, therefore, considered these integrative outcomes as a valuable contribution to this study.

The quality of data had to illustrate compliance with aspects of autonomy, beneficence and justice (Orb, Eisenhauer \& Wynaden 2000). Evidence in support of autonomy can be traced to informed notice and consent received from the ANSP and participants. Beneficence was achieved by not revealing the participants' identities. Justice was evident from descriptions detailing the vulnerability of the participants and their contributions to the study. The rights of human subjects were also protected by, for example, not affecting emotional harm, and not encroaching on their rights to maintain self-respect and human dignity. Moreover, data were collected, examined and stated by providing all information without misrepresentation, not consciously ascribing greater confidence than the measurements warranted and recording contradictory evidence.

The internal validity of Wilson's (2004) EDLTI and the EDLBI was established by an expert panel. An expert panel review aimed at strengthening the content validity of the Leader Trait and Behaviour Questionnaire suggested negligible changes, which were included in the final Leader Trait and Behaviour Questionnaire. Construct validity of the Leader Trait and Behaviour Questionnaire was traced to the literature review with reference to a synopsis of leader trait and behaviour groups that resulted. Maxwell's (2009) sevenpoint checklist for validity in qualitative research was used. Compliance subsequently becomes apparent in terms of the concentrated long-term involvement in the research setting, comprehensive data collection, confirming respondent validation, reporting discrepant evidence and negative cases, triangulation, use of different data sources, use of quasistatistics and comparing results across different settings and groups within a specific context.

\section{Reliability}

Reliability in terms of qualitative research was facilitated by ensuring that all interview questions were derived from the literature review, distinct interview modus operandi were consistently applied, adhering to sampling criteria, guaranteeing confidentiality and ensuring ethical compliance. Furthermore, inter-coder reliability (Kohlbacher 2005; Mayring 2003) was confirmed by an external codifier. A Cronbach's alpha was used to confirm internal consistency and to determine good inter-item correlation of the Leader Trait and Behaviour Questionnaire (Table 6). The Leader Trait and Behaviour Questionnaire had good internal consistency, with Cronbach's alpha coefficients reported above 0.7. Arrangements to confirm reliability were also consciously consolidated and strengthened during triangulation.

Designated trustworthiness schemes complied with Gall, Borg and Gall (1996) and Krefting's (1991) recommendations to take account of triangulation, member-checking and to demonstrate a logical association between research questions, research procedures, raw data and outcomes. Furthermore, a similar format, sequence and questions for each participant were used. Also, thorough descriptions of participants, the sample drawn, data collection procedures and detailed transcripts of information collected were offered.

\section{Findings}

The aim of this study was to examine, understand and appreciate experiences and expectations of followers (within an ANSP context) of leadership behaviours. The intention was to analyse and report on the multiple realities associated with mentioned specific phenomenon. A total of 14 themes were revealed. A summary is presented:

- leadership as a construct

- followership as a construct

- contextualised leadership roles and responsibilities

- insight into the leader-follower relationship

- behaviours supporting effective leadership from a team viewpoint

- behaviours labelling less effective leadership from a team viewpoint

- behaviours supporting effective leadership from a follower mental model view

- behaviours that define less effective leadership from a follower's perspective

- behaviours that reinforce effective leadership in a particular context

- less effective leadership behaviours in a specific context

- leader and leadership behaviour qualities (within an ANSP)

- leader and leadership behaviour qualities that enthused followership (within an ANSP)

- leader and leadership behaviour qualities that discouraged followership (within an ANSP)

- leadership was apparent in the participants' questioning attitudes, acceptance of dependence, professional commitment, openness to contribute, enthusiasm and excitement. 
TABLE 6: Reliability statistics for the Leader Trait Questionnaire.

\begin{tabular}{|c|c|c|c|c|c|c|}
\hline \multirow[t]{2}{*}{ Trait } & \multirow[t]{2}{*}{ Variable } & \multicolumn{2}{|c|}{ Case processing summary } & \multicolumn{3}{|c|}{ Reliability statistics } \\
\hline & & $N$ & $\%$ & Cronbach's alpha & $\begin{array}{l}\text { Cronbach's alpha based } \\
\text { on standardised items }\end{array}$ & No. of items \\
\hline \multirow[t]{3}{*}{ Dedicated } & Valid & 145 & 100.0 & - & - & - \\
\hline & Excluded & 0 & 0.0 & - & - & - \\
\hline & Total & 145 & 100.0 & 0.960 & 0.961 & 17 \\
\hline \multirow[t]{3}{*}{ Practical } & Valid & 145 & 100.0 & - & - & - \\
\hline & Excluded & 0 & 0.0 & - & - & - \\
\hline & Total & 145 & 100.0 & 0.916 & 0.918 & 12 \\
\hline \multirow[t]{3}{*}{ Cooperative } & Valid & 145 & 100.0 & - & - & - \\
\hline & Excluded & 0 & 0.0 & - & - & - \\
\hline & Total & 145 & 100.0 & 0.925 & 0.924 & 10 \\
\hline \multirow[t]{3}{*}{ Assertive } & Valid & 145 & 100.0 & - & - & - \\
\hline & Excluded & 0 & 0.0 & - & - & - \\
\hline & Total & 145 & 100.0 & 0.906 & 0.906 & 12 \\
\hline \multirow{2}{*}{ Personable } & Excluded & 0 & 0.0 & - & - & - \\
\hline & Total & 145 & 100.0 & 0.894 & 0.895 & 8 \\
\hline \multirow[t]{6}{*}{ Analytical } & Valid & 144 & 99.3 & - & - & - \\
\hline & Excluded & 1 & 0.7 & - & - & - \\
\hline & Total & 145 & 100.0 & 0.669 & 0.675 & 4 \\
\hline & Valid & 145 & 100.0 & - & - & - \\
\hline & Excluded & 0 & 0.0 & - & - & - \\
\hline & Total & 145 & 100.0 & 0.771 & 0.771 & 3 \\
\hline
\end{tabular}

Note: Within the analytical factor (trait), it was decided to include items B4 (analytical), B8 (broad skills) and B14 (concentrated). Because factor analysis searches for joint variations in response to unobserved latent variables, the information gained about the interdependencies between observed variables was used to find sets of variables in a dataset that could be reduced. This meant that the least number of factors that can account for the common variance (correlation) of a set of variables was noted. As a result, item B13 (complex thinker) was omitted because of its low corrected item-to-total correlation.

TABLE 7: Reliability statistics for the Leader Behaviour Questionnaire.

\begin{tabular}{|c|c|c|c|c|c|c|}
\hline \multirow[t]{2}{*}{ Behaviour } & \multirow[t]{2}{*}{ Variable } & \multicolumn{2}{|c|}{ Case processing summary } & \multicolumn{3}{|c|}{ Reliability statistics } \\
\hline & & $N$ & $\%$ & Cronbach's alpha & $\begin{array}{l}\text { Cronbach's alpha based } \\
\text { on standardised items }\end{array}$ & Number of items \\
\hline \multirow[t]{3}{*}{ Focused } & Valid & 144 & 99.3 & - & - & - \\
\hline & Excluded & 1 & 0.7 & - & - & - \\
\hline & Total & 145 & 100.0 & 0.965 & 0.966 & 17 \\
\hline \multirow[t]{3}{*}{ Supportive } & Valid & 145 & 100.0 & - & - & - \\
\hline & Excluded & 0 & 0.0 & - & - & - \\
\hline & Total & 145 & 100.0 & 0.974 & 0.974 & 23 \\
\hline \multirow[t]{3}{*}{ Developer } & Valid & 145 & 100.0 & - & - & - \\
\hline & Excluded & 0 & 0.0 & - & - & - \\
\hline & Total & 145 & 100.0 & 0.956 & 0.956 & 12 \\
\hline \multirow[t]{3}{*}{ Advisor } & Valid & 145 & 100.0 & - & - & - \\
\hline & Excluded & 0 & 0.0 & - & - & - \\
\hline & Total & 145 & 100.0 & 0.955 & 0.955 & 12 \\
\hline \multirow{2}{*}{ Competitive } & Excluded & 0 & 0.0 & - & - & - \\
\hline & Total & 145 & 100.0 & 0.875 & 0.875 & 9 \\
\hline \multirow[t]{3}{*}{ Delegator } & Valid & 145 & 100.0 & - & - & - \\
\hline & Excluded & 0 & 0.0 & - & - & - \\
\hline & Total & 145 & 100.0 & 0.945 & 0.945 & 15 \\
\hline \multirow[t]{3}{*}{ Charismatic } & Valid & 145 & 100.0 & - & - & - \\
\hline & Excluded & 0 & 0.0 & - & - & - \\
\hline & Total & 145 & 100.0 & 0.874 & 0.874 & 6 \\
\hline
\end{tabular}

\section{Discussion}

\section{Answers to the four research questions used to translate the research question for research design}

\section{Question 1}

How do followers within an ANSP describe leadership behaviour qualities in terms of the impact of these behaviour qualities?
In summary, occurrences, descriptions, experiences, perceptions and explanations of leadership reported in the workplace were formed and guided by followers' reflection, awareness and reasoning. Followers understood, noted, rated, presented and described the workplace as a unit (inclusive of both work and social perspectives/influences) within which preferred and undesired leader qualities as well as leader and follower dissimilarities and similarities could be observed. 
An important and respected 'own follower voice' emerged. Followers' reflection, awareness and reasoning pertaining to leadership suggested that they perceive and identify themselves from a dutiful, passive and compliant perspective.

\section{Question 2}

How do current leadership behaviour qualities enthuse followership within an ANSP?

A brief review is offered. Followers' accounts, reports and explanations of leadership characteristics and competence showed that preferred leader qualities, behaviours, dealings and experiences were distinguishable and could be explained in terms of significance and benefit. Leader behaviours that could suggest improved follower performance and leadership behaviour qualities that may conjure progressive followership were acknowledged. Leadership experiences and expectations associated with positive leader support, follower advancement, as well as assertive and pragmatic leadership that supported transformational leadership, were preferred by followers.

\section{Question 3}

How do current leadership behaviour qualities demotivate followership within an ANSP?

Noteworthy insights are presented. Followers' descriptions of undesired/discouraging leadership characteristics showed that such leader traits, behaviours, interactions and experiences were apparent, distinguishable and were explained in terms of apprehension and dissatisfaction. Followers acknowledged that these undesired behaviours could potentially impede their performance. Furthermore, behaviour qualities that did not induce positive followership were acknowledged. In response, it was found that leadership experiences and expectations supportive of leader backing and follower development, along with firm and pragmatic leadership that underlined transformational leadership, were preferred by followers. Practical examples of leadership events that were not preferred by followers were provided by the participants. These were expressed as:

'leaders ... when it comes to implementation we are a bit lacking; you are just frustrated and you take it out on the guys that need you; in some cases too many people to report to and leadership in our department is seems as if they're against their follower, they gave the other party the impression that I was wrong, leaders bending the rules a bit.' [Focus Group 224, Females, Air Traffic Controllers]

Additionally, leader traits exemplifying slow responsiveness, workplace frustration, follower-leader relationship anxieties and concerns regarding risk-taking were specified. Consequently, it was concluded that ineffective transactional leaders may be less likely to anticipate problems, difficulties and complications, whereas more effective transactional leaders take suitable action in a timely manner. This deliberation offers added support and approval for a transformational leadership style. According to Avolio, Waldman and Einstein (1988), Singer and Singer (1990), Yammarino and Bass (1990) and Roberts (1985), transformational leadership supports better group process, contentment and productivity and strengthens individual empowerment.

\section{Question 4}

How can follower experiences and expectations of leadership behaviours within an ANSP benefit leadership training and development needs analyses?

In summary, it was established that followers could sensibly evaluate, interpret and describe leader and leadership behaviours. Subsequently, followers recognised a need for both successful leadership and teamwork guided by vocational competence. Finally, a realisation that leaders had to appreciate, recognise and accept their organisational, team and employee roles and responsibilities were conveyed by followers.

\section{Limitations and suggestions for future research}

As a limitation of this study, it should be noted that leadership was excluded. Research findings and contextualising of results are only pertinent to this study. Therefore, generalisation outside of this context is not inferred. It is accepted that different data collection strategies and different research methods could be used to promote understanding of this topic. Finally, different researchers may or may not support all the findings when reanalysing the collected data.

Future inquiry aimed at determining the necessity to educate followers to be able to critically appreciate and evaluate leadership performance may be valuable. Also, a greater understanding of how followers' mental models internally represent complex, dynamic systems and how these representations change over time may also serve as a theme for future research. Resulting research results may assist leadership training and development specialists to develop or improve leadership training and development.

\section{Conclusion}

This study offered a systematic process that can be considered in pursuit of leadership development, enhancement and success. Data collected, analysed and reported may aid the design, implementation and evaluation of fit-for-purpose leadership training and development solutions and interventions. Possibly, this approach can also assist organisations to recognise, develop and implement an integrated leadership training and development approach, mindful that such an intervention should satisfy the identified needs that will enable leaders to learn, develop and experience the intended knowledge, skills and attitudes. It is proposed that mentioned leadership training and development could develop, strengthen and inculcate desired leadership behaviour qualities, which in turn may inspire sought-after followership. Leadership is not static, and it was acknowledged that the roles and responsibilities of leaders are constantly shifting as a result of environmental and employee dynamics. Accordingly, leadership training and development initiatives are acknowledged as continued undertakings. 
The value resulting from this study may be found by recognising the existence and impact of individual and shared mental models (followers' 'inner-voices'). Furthermore, followers can indeed clearly describe desired and undesired leader-follower relationships. Hence, it was also promising to note the level of insight and value of follower experiences and expectations of leadership behaviours. Furthermore, the particular influence of the organisational context was accentuated by this study. Research findings may contribute towards identifying and describing leadership qualities and behaviours that ought to be incorporated and excluded as part of learning and training interventions. Subsequently, a leadership training and development needs analysis framework (albeit within a specific context) emerged. This needs analysis highlights the need to gain collective follower insights by exploring the theories-in-use and espoused theories held by followers (thus, constituting a prevailing mental model).

In terms of research process, data collection methods for both inspirational and discouraging leader behaviours (directed by followers' involvement and beliefs within a defined context) were revealed. Data analysis phases used for both inspirational and discouraging leader behaviours were also described. Furthermore, the importance and value of triangulation as a precursor for the clarification of findings were explained. Finally, it may be conceded that the research findings can be used to present and outline a leadership training and development framework.

\section{Acknowledgements Competing interests}

The authors declare that they have no financial or personal relationships that may have inappropriately influenced them in writing this article.

\section{Authors' contributions}

J.A.F.'s assisted C.G.J. with the choice of research paradigm and ways to achieve triangulation for increased validity and reliability. J.A.F. also assisted with the choice of the focus of an article that would be produced to relate the central and practical features of the research. J.A.F. wrote the article with C.G.J. and had it critically read by peers at the School of Business Leadership. C.G.J.'s contributed the actual design and operationalization of the research, guided by Feldman. C.G.J had intimate ownership of the research steps and, in consultation with Feldman, processed all the revisions of the article as directed by South African Journal of Economic and Management Sciences to produce the finished article.

\section{References}

Avolio, B.J., Waldman, D.A. \& Einstein, W.O., 1988, 'Transformational leadership in a management game simulation', Group \& Organization Studies 13(1), 59-80. https://doi.org/10.1177/105960118801300109

Avolio, B.J., Walumbwa, F.O. \& Weber, T.J., 2009, 'Leadership: Current theories, research, and future directions', Annual Review of Psychology 60, 421-449. https://doi.org/10.1146/annurev.psych.60.110707.163621
Baicher, R., 2005, 'Leadership competencies of successful business leaders in South Africa', MBL dissertation, University of South Africa.

Banutu-Gomez, M.B., 2004, 'Great leaders teach exemplary followership and serve as servant leaders', Journal of American Academy of Business 4(1/2), 143-150.

Bjugstad, K., Thach, E.C., Thompson, K.J. \& Morris, A., 2006, 'A fresh look at followership: A model for matching followership and leadership styles', Journal of Behavioral and Applied Management 7, 304-319.

Boccialetti, G., 1995, It takes two: Managing yourself when working with bosses and other authority figures, Jossey-Bass, San Francisco, CA.

Boezeman, E.J. \& Ellemers, N., 2008, 'Pride and respect in volunteers organizational commitment', European Journal of Social Psychology 38(1), 159-172. https://doi. org/10.1002/ejsp.415

Brown, M.E. \& Mitchell, M.S., 2010, 'Ethical and unethical leadership: Exploring new avenues for future research', Business Ethics Quarterly 20(4), 583-616. https:// doi.org/10.5840/beq201020439

Brown, M.E. \& Trevino, L.K., 2006, 'Ethical leadership: A review and future directions', The Leadership Quarterly 17, 595-616. https://doi.org/10.1016/j.leaqua.2006.10.004

CANSO, 2010, The Civil Air Navigation Services Organisation (CANSO): The nextgeneration aviation professional, CANSO and IFATCA Publication, Hoofddorp, The Netherlands.

CANSO, 2011, The Civil Air Navigation Services Organisation (CANSO) Global Vision The future of air traffic management, CANSO Publication, Hoofddorp, The Netherlands.

Castro, C.B., Perinan, M.M.V. \& Bueno, J.C.C., 2008, 'Transformational leadership and followers' attitudes: The mediating role of psychological empowerment', The International Journal of Human Resource Management 19(10), 1842-1863. https://doi.org/10.1080/09585190802324601

Chaleff, I., 1995, The courageous follower: Standing up to and for our leaders, BerrettKoehler Publishers, San Francisco, CA.

Collinson, D., 2006, 'Rethinking followership: A post-structuralist analysis of followe identities', The Leadership Quarterly 17, 179-189. https://doi.org/10.1016/j. leaqua.2005.12.005

Creswell, J.W., 2003, Research design: Qualitative, quantitative, and mixed methods approaches, 2 nd edn., Sage, Thousand Oaks, CA.

Cropanzano, R., Byrne, Z.S., Bobocel, D.R. \& Rupp, D.E., 2001, 'Moral virtues, fairness heuristics, social entities, and other denizens of organizational justice', Journal of Vocational Behavior 58, 164-209. https://doi.org/10.1006/jvbe.2001.1791

Cropanzano, R. \& Mitchell, M.S., 2005, 'Social exchange theory: An interdisciplinary review', Journal of Management 31, 874-900. https://doi.org/10.1177/ review', Journal of

Den Hartog, D.N. \& Belschak, F.D., 2012, 'When does transformational leadership enhance proactive behaviour? The role of autonomy and role breadth self-efficacy', Journal of Applied Psychology 97(1), 194-202. https://doi.org/10.1037/a0024903

Eisenberger, R., Fasolo, P. \& Davis-LaMastro, V., 1990, 'Perceived organizational support and employee diligence, commitment, and innovation', Journal of Applied Psychology 75, 51-59. https://doi.org/10.1037/0021-9010.75.1.51

Gall, M.D., Borg, W.R. \& Gall, J.P., 1996, Educational research: An introduction, Longman, White Plains, New York.

Gray, J.H. \& Densten, I.L., 2007, 'How leaders woo followers in the romance of leadership', Applied Psychology: An International Review 56(4), 558-581. https:// doi.org/10.1111/j.1464-0597.2007.00304.x

Greene, J.C., Caracelli, V.J. \& Graham, W.F., 1989, 'Toward a conceptual framework for mixed-method evaluation designs', Educational Evaluation and Policy Analysis 11(3), 255-274. https://doi.org/10.3102/01623737011003255

Heyl, B.S., 2001, 'Ethnographic interviews', in P. Atkinson, A. Coffey, S. Delamont, J. Lofland \& L. Lofland (eds.), Handbook of ethnography, pp. 369-383, Sage, London.

Hill, L.A. \& Lineback, K., 2011, Being the boss: The three imperatives for becoming a great leader, Harvard Business Review Press, Boston, MA.

Hogg, M.A., 2001, 'A social identity theory of leadership', Personality and Socia Psychology Review 5(3), 184-200. https://doi.org/10.1207/S15327957PSPR0503_1

Hollander, E.P., 1992a, 'Leadership, followership, self, and others', Leadership Quarterly 3, 43-44. https://doi.org/10.1016/1048-9843(92)90005-Z

Hollander, E.P., 1992b, 'The essential interdependence of leadership and followership', Current Directions in Psychological Science 1(2), 71-75. https://doi. org/10.1111/1467-8721.ep11509752

Hollander, E.P., 1995, 'Ethical challenges in the leader-follower relationship', Business Ethics Quarterly 5(1), 55-65. https://doi.org/10.2307/3857272

Howell, J.M. \& Haii-Merenda, K.E., 1999, 'The ties that bind: The impact of leadermember exchange, transformational leadership and transactional leadership, and distance on predicting follower performance', Journal of Applied Psychology 84 680-694. https://doi.org/10.1037/0021-9010.84.5.680

Hur, M.H., 2008, 'Exploring differences in leadership style: A study of manager tasks, follower characteristics and task environments in Korean human service organization', Social Behavior and Personality 36(3), 359-372. https://doi. org/10.2224/sbp.2008.36.3.359

Hutchison, S. \& Garstka, M.L., 1996, 'Sources of perceived organizational support: Goal setting and feedback', Journal of Applied Social Psychology 26, 1351-1366. https://doi.org/10.1111/j.1559-1816.1996.tb00075.x

Ibarra, H. \& Barbulescu, R., 2010, 'Identity as narrative: Prevalence, effectiveness, and consequences of narrative identity work in macro work role transitions', Academy of Management Review 35, 135-154. https://doi.org/10.5465/AMR.2010.45577925 
Ilies, R., Morgeson, F.P. \& Nahrgang, J.D., 2005, 'Authentic leadership and eudaemonic well-being: Understanding leader-follower outcomes', The Leadership Quarterly 16, 373-394. https://doi.org/10.1016/j.leaqua.2005.03.002

Johnson, R.B. \& Onwuegbuzie, A.J., 2004, 'Mixed methods research: A research paradigm whose time has come', Educational Researcher 33(7), 14-26. https:// doi.org/10.3102/0013189X033007014

Johnson-Laird, P.N., 2013, 'Mental models and cognitive change', Journal of Cognitive Psychology 25(2), 131-138. https://doi.org/10.1080/20445911.2012.759935

Kellerman, B., 2004, Bad leadership: What it is, how it happens, why it matters, Harvard Business School Press, Boston, MA.

Kellerman, B., 2007, 'What every leader needs to know about followers', Harvard Business Review, 85(12), 84-91.

Kellerman, B., 2008, Followership: How followers are creating change and changing leaders, Harvard Business School Publishing, Boston, MA

Kelley, R.E., 1992, The power of followership: How to create leaders people want to follow and followers who lead themselves, Doubleday Currency, New York.

Kirchhubel, D., 2010, 'Effective "Followership" How to manage upwards', British Journal of Administrative Management Autumn, 18-19.

Knauff, M., Bucher, L., Krumnack, A. \& Nesjasmic, J., 2013, 'Spatial belief revision', Journal of Cognitive Psychology 25, 139-146. https://doi.org/10.1080/20445911. 2012.751910

Kohlbacher, F., 2005, 'The use of qualitative content analysis in case study research' Forum Qualitative Sozialforschung/Forum: Qualitative Social Research 7(1), Art.
21 , viewed 03 September 2011, from http://www.qualitative-research.net/ 21, viewed 03 September
fqstexte/1-06/06-1-21-e.htm

Krefting, L., 1991, 'Rigor in qualitative research: The assessment of trustworthiness', The American Journal of Occupational Therapy 45(3), 214-221. https://doi. The American Journal of
org/10.5014/ajot.45.3.214

Kupers, W., 2007, 'Perspectives on integrating leadership and followership', International Journal of Leadership Studies 2(3), 194-221.

Lincoln, Y.S. \& Guba, E.G., 1985, Naturalistic inquiry, Sage, Newbury Park, CA.

Lord, R.G. \& Brown, D.G., 2004, Leadership processes and follower self-identity, Lawrence Erlbaum Associates, Mahwah, NJ.

Madera, J.M. \& Smith, D.B., 2009, 'The effects of leader negative emotions on evaluations of leadership in a crisis situation: The role of anger and sadness', Leadership Quarterly 20, 103-114. https://doi.org/10.1016/j.leaqua.2009.01.007

Mayo, M. \& Pastor, J.C., 2007, 'Leadership embedded in Social networks': A look at inter-follower processes' in B. Shamir, R. Pillai, M.C. Bligh. \& M. Uhi-Bien (eds.), Follower-centered perspectives on leadership, pp. 93-114, Information Age Follower-centered perspective
Publishing, Greenwich, CT.

Mayring, P., 2003, Qualitative Inhaltsanalyse, Grundlagen und Techniken, 8th edn., Beltz, UTB, Weinheim.

Maxwell, J.A., 2009, 'Designing a qualitative study', in L. Sickman \& D.J. Rog (eds.), The Sage handbook of applied social research methods, 2nd edn., 214-253, Sage, Thousand Oaks, CA.

McCann, J.J., Langford, P.H. \& Rawlings, R.M., 2006, 'Testing Behling and McFillen's Syncretical Model of charismatic transformational leadership', Group \& Organization Management 31, 237-263. https://doi.org/10.1177/1059601104273061

McMillan, J.H. \& Schumacher, S., 2001, Research in education: A conceptual introduction, 5th edn., Addison Wesley Longman, Inc., New York.

Morris, A., Ely, R.J. \& Frei, F.X., 2011, 'Stop holding yourself back', Harvard Business Review January-February, 160-163.

Mouton, J., 2001, How to succeed in your master and doctoral studies, Van Schaik Publisher, Pretoria.

Mushonga, S.M. \& Torrance, C.G., 2008, 'Assessing the relationship between followership and the big five factor model of personality', Review of Business Research 8(6), 185-193.

Noor, K.B.M., 2008, 'Case study: A strategic research methodology', American Journa of Applied Sciences 5(11), 1602-1604. https://doi.org/10.3844/ajassp.2008. 1602.1604

Ohman, A., 2005, 'Qualitative methodology for rehabilitation research', Journa Rehabilitation Medicine 37,273-280. https://doi.org/10.1080/16501970510040056

Orb, A., Eisenhauer, L. \& Wynaden, D., 2000, 'Ethics in qualitative research', Journal of Nursing Scholarship 33(1), 93-96. https://doi.org/10.1111/j.1547-5069.2001.00093.x

Patton, E. \& Appelbaum, S.H., 2003, 'The case for case studies in management research', Management Research News 26(5), 60-71. https://doi.org/10.1108/ 01409170310783484
Riggio, R.E., Chaleff, I. \& Lipman-Blumen, J., 2008, The art of followership: How great followers create great leaders and organizations, Jossey-Bass, San Francisco, CA.

Roberts, N., 1985, 'Transforming leadership: A process of collective action', Human Relations 38(11), 1023-1046. https://doi.org/10.1177/001872678503801103

Rousseau, D.M., 2010, 'The individual-organization relationship: The psychological contract', in S. Zedeck (ed.), APA handbook of industrial and organizational psychology, vol. 3, Maintaining, expanding and contracting the organization, pp. 191-214, American Psychological Association, Washington, DC.

Saunders, M., Lewis, P. \& Thornhill, A., 2007, Research methods for business students, 4th edn., Pearson Education Limited, Essex.

Settoon, R.P., Bennett, N. \& Liden, R.C., 1996, 'Social exchange in organizations: Perceived organizational support, leader-member exchange, and employee reciprocity', Journal of Applied Psychology 81, 219-227. https://doi.org/10. 1037/0021-9010.81.3.219

Shamir, B., 2007, 'From passive recipients to active co-producers: Followers' roles in the leadership process', in B. Shamir, R. Pillai, M.C. Bligh \& M. Uhi-Bien (eds.), the lleadership process', in B. Shamir, R. Pillai, M.C. Bligh \& M. Uhi-Bien (eds.), Follower-centered perspectives on leadership: A tribute
Meindl, pp. ix-xxxix, Information Age, Greenwich, CT.

Shamir, B \& Howell, J.M., 1999, 'Organizational and contextual influences on the emergence and effectiveness of charismatic leadership', Leadership Quarterly 10(2), 257-283. https://doi.org/10.1016/S1048-9843(99)00014-4

Singer, M.S. \& Singer, A.E., 1990, 'Situational constraints on transformational versus transactional leadership behavior, subordinates' leadership preference, and satisfaction', Journal of Social Psychology 130(3), 385-396. https://doi.org/10.108 0/00224545.1990.9924594

Steinbauer, R., Renn, R.W., Taylor, R.R. \& Njoroge, P.K., 2013, 'Ethical leadership and followers' moral judgement: The role of followers' perceived accountability and self-leadership', Journal of Business Ethics 120(3), 381-392. https://doi. org/10.1007/s10551-013-1662-x

Stetz, T.A., Stetz, M.C. \& Bliese, P.A., 2006, 'The importance of self-efficacy in the moderating effects of social support on stressor-strain relationships', Work \& Stress 20, 49-59. https://doi.org/10.1080/02678370600624039

Van Vugt, M., 2006, 'Evolutionary origins of leadership and followership', Personality and Social Psychology Review 10(4), 354-371. https://doi.org/10.1207/ s15327957pspr1004_5

Vroom, V.H. \& Jago, A.G., 1988, The new leadership: Managing participation in organizations, Prentice Hall, Englewood Cliffs, NJ.

Walshe, C.E., Caress, A.L., Chew-Graham, C. \& Todd, C.J., 2004, 'Case studies: A research strategy appropriate for palliative care?', Palliative Medicine 18, 677684. https://doi.org/10.1191/0269216304pm962ra

Wang, H., Sui, Y., Luthans, F., Wang, D. \& Wu, Y., 2014, 'Impact of authentic leadership on performance: Role of followers' positive psychological capital and relational processes', Journal of Organizational Behavior 35(1), 5-21. https://doi. processes', Journal of

Wayne, S.J., Shore, M. \& Liden, R.C., 1997, 'Perceived organizational support and leader-member exchange: A social exchange perspective', Academy of Management Journal 40, 82-111. https://doi.org/10.2307/257021

Weichun, Z., Sosik, J.J., Riggio, R.E. \& Baiyin, Y., 2012, 'Relationships between transformational and active transactional leadership and followers' organizational identification: The role of psychological empowerment ', Journal of Behavioral and Applied Management 13(3), 186-212.

Whitener, E.M., 2001, 'Do "high commitment" human resource practices affect employee commitment? A cross-level analysis using hierarchical linear modelling', Journal of Management 27, 515-535.

Wilson, M.S., 2004, 'Effective developmental leadership: A study of the traits and behaviours of a leader who develops both people and the organization', PhD thesis, Louisiana State University, LA.

Wong, C.S. \& Law, K.S., 2002, 'The effects of leader and follower emotional intelligence on performance and attitude: An exploratory study', The Leadership Quarterly 13, 243-274. https://doi.org/10.1016/S1048-9843(02)00099-1

Wood, M., 2005, 'The fallacy of misplaced leadership', Journal of Management Studies 42(6), 1101-1121. https://doi.org/10.1111/j.1467-6486.2005.00535.x

Yammarino, F.J. \& Bass, B.M., 1990, 'Transformational leadership and multiple levels of analysis',HumanRelations43,975-995.https://doi.org/10.1177/001872679004301003

Yin, R.K., 2003, Case study research, design and methods, 3rd edn., vol. 5, Sage, Thousand Oaks, CA.

Yin, R.K., 2011, Qualitative research from start to finish, Guilford Press, Guilford Publications, Inc., New York

Yukl, G.A., 2005, Leadership in organizations, 6th edn., Prentice Hall, Englewood Cliffs, NJ. 